\title{
The 'Art' of Colonisation: Capitalising Sovereign Power and the Ongoing Nature of Primitive Accumulation
}

\author{
TIM DI MUZIO
}

In order to dispel Adam Smith's liberal narrative of original accumulation, Karl Marx offered his own historical account of the rise of capitalism in England. He also pointed to the English colonies, where the conditions for capitalist development were being created by government intervention in his own era. ${ }^{1}$ Playing on the discussion of the 'art of colonisation' in Edward Gibbon Wakefield's comparative study of England and America, Marx argued that Wakefield's candid advice on colonial policy and prosperity revealed the shaky foundations upon which Adam Smith's concept of original accumulation was built. According to Marx, the value of Wakefield's work rested in his recognition that the social property relations of capital did not evolve naturally and spontaneously as liberal speculative history might imply, but had to be enforced by state power. In this case, 'wasteland' in America had to be sufficiently priced so as to render it difficult for most immigrants to obtain land. ${ }^{2}$ Without access to affordable land, newcomers to America would have little choice outside starvation but to work for someone else upon arrival. In this way, state policy featured as a prominent lever of primitive accumulation insofar as it blocked people from gaining the means by which they could work for themselves and their families. Thus, even a cursory consideration of state policy in the colonies made a mockery of Adam's Smith's claim that capital was 'silently and gradually accumulated by the private frugality and good conduct of individuals, by their universal, continual and uninterrupted effort to better their own condition'?

One would not be too hard pressed to find the liberal intelligentsia pontificating on 'the art of colonisation' today, though with the important caveat that the permanent territorial administration of a country is not needed to effect a transformation in social property relations. However, while direct colonisation or annexation of a political community is seldom argued for, what seems to be unfolding in our own era is the development of knowledge and practices for a new art of military intervention premised on the temporary occupation and technocratic reconstruction-reconstitution of illiberal societies. ${ }^{4}$ While critical

Tim Di Muzio, Institute for International Development, University of Oxford, 3 Mansfield Road, Oxford OX1 3TB, UK. 
theorists largely interpret this development as a return to imperialism under US authority, militant liberals and others prefer to cast it as a benevolent US-led state-building project that will eventually provide for a peaceful world order once 'failed states' are reconstituted as liberal-capitalist polities.

While Mark T. Berger has argued for the need to situate resurgent state-building discourse and practices within a longer historical trajectory, the new sense of urgency and the development of knowledge/power embedded in state-building projects appears to be informed by a burgeoning discourse on failed states. ${ }^{5}$ Indeed, one of the key phrases in the National Security Strategy of the United States 2002 advised that the USA and its allies are 'less threatened by conquering states than ... failing ones'. ${ }^{6}$ This may sound like a radically new strategic concern since it appears to marginalise balance of power theorisations, but it follows on from a trend studied by Mark Duffield in the late 1990s: the idea that underdevelopment has become 'dangerous' and efforts need to be made to transform such societies into pacified liberal-capitalist polities. ${ }^{7}$ However, what many critics of the war on terror or US imperialism have so far failed to appreciate is how this project would be impossible without the capitalisation of the state. In this article, I therefore want to suggest that Marx's re-theorisation of the concept of primitive accumulation, combined with a non-Marxist theorisation of state power offered by Jonathan Nitzan and Shimshon Bichler, can help us account for the intimate connection between ongoing primitive accumulation and the capitalisation of the US government.

While Marx identified a number of mechanisms that led to the social property relations of capital, one of the most important was the power of the state. Here, Marx recognised that the creation of the national debt in England was of crucial importance to the development of capitalist sociality. The national debt not only offered the propertied classes of England and other nations a secure and profitable refuge for their money, but it also gave Parliament the required finance it needed to facilitate and defend the accumulation of capital for the propertied class. At the same time, the creation of the public debt gradually shifted the burden of repayment onto the whole of English society - not to mention the colonies through a more extensive system of taxation and the creation of new 'national' debts abroad. One of the major ways the facilitation and defence of accumulation was accomplished was through wars of conquest and subsequent transformations in the social property relations of the periphery. ${ }^{8}$

In a similar way, the temporary occupation and market-making reforms attempted in Iraq, Afghanistan and Haiti also rely on the national debt and the confidence of domestic and foreign investors. The major difference in the contemporary period is that it is primarily on the basis of the public debt of the USA that the advancement of primitive accumulation by force continues. However, while it may be argued that these new interventions hinge on US sovereign debt, Marx never explicitly developed a theory of the capitalisation of the state. Somewhat ironically, this theorisation has instead been developed by two political economists working outside the Marxist tradition. Rejecting both the neoclassical utility theory of value as well as Marx's labour theory of value, Nitzan and Bichler offer a power theory of value that approaches capitalism from the viewpoint of capitalisation. ${ }^{9}$ From this standpoint, there are at least two crucial questions that 
must be asked: (1) what is being capitalised?; and (2) for what purposes is this entity being financed? Rich empirical work on what Nitzan and Bichler call 'dominant capital' lead them to argue that (1) capital can be theorised as a form of commodified power, (2) this power is primarily aimed at shaping and reshaping the terrain of social reproduction, and (3) its accumulation must be measured differentially rather than absolutely. ${ }^{10}$ Because the state can be conceived of as a capitalised entity measured by the pecuniary value of its public debt, Nitzan and Bichler have argued that investors capitalise the state's power to tax and shape the landscape of social reproduction when they purchase government securities.

To explore the ways in which the concept of primitive accumulation and Nitzan and Bichler's theorisation of the state can contribute to theorising the connection between the new interventions and the ongoing capitalisation of the US government, I have divided the article in the following way. First, I address one of the current debates on whether the concept of primitive accumulation remains useful for understanding key components of globalisation, political economy and the constitution and reconstitution of world order. My argument here is that the concept remains useful for understanding historical transitions not only to capitalist social property relations but also a more marketised and commodified world order. ${ }^{11}$ This is so for two main reasons. First, capitalist social property relations have not spread uniformly and they cannot be said to pervade all human societies in an equal manner. Second, it is possible to conceive of resistance as a constitutive moment of primitive accumulation since peoples have struggled - often successfully - to erect social barriers to the full mediation of their lives by the imperatives of the capitalist market. ${ }^{12}$ To evaluate the usefulness of primitive accumulation as a concept, I engage primarily with the work of Nitzan and Bichler and their novel theory of capital and accumulation. I do so not only because they offer one of the most convincing non-Marxist theories of capitalism, but also because those concerned with capitalist globalisation have so far refused to consider their important arguments. Here I try to show that we can accept their novel theory of capital as a capitalised and commodified form of power, but argue that the concept of primitive accumulation still has considerable analytical value for theorising the extension and depth of capitalist social property relations within and across political jurisdictions.

After having established the relevance of the concept of primitive accumulation, I consider the role of the politico-military apparatus of the USA in advancing primitive accumulation by pointing to the series: sovereignty-primitive accumulation-social reproduction. The main argument advanced here is that it is possible to conceive of the politico-military apparatus of the USA as a capitalised agency whose strategic goal is not simply to secure a more encompassing form of economic globalisation, but to introduce and intensify what Marx called 'the silent compulsion of the market' across political jurisdictions sheltered from the complete instantiation of market imperatives. This is not to suggest that agencies within the USA are the sole force seeking to strengthen the dictates of the market by transforming illiberal political economies into liberal capitalist states. ${ }^{13}$ However, because the politico-military apparatus of the USA does play a unique role in shaping world order, most of my focus will be on theorising why the sovereign power of the USA is capitalised by investors. ${ }^{14}$ Here, I consider 
the joint work of Wall Street and Pentagon strategists since their observations go a long way in demonstrating how investors think about financing the US state and how this finance is understood as vital to projects that seek to shape the global terrain of social reproduction and the future of world order. In the final section, I offer evidence from Iraq to support the claim that the concept of primitive accumulation combined with a new theorisation of state power can help us understand current attempts to reconstitute the political economies of occupied societies.

\section{Theorising primitive accumulation and the international}

There has been something of a revival of the concept of primitive accumulation across academic disciplines. One of the main debates considers whether mechanisms of primitive accumulation are ongoing or whether the concept should be confined to describing the initial transition to the social property relations of capital. ${ }^{15}$ If the latter proves to be the case, then we would do well simply to focus on the mechanisms and logic of contemporary accumulation and cease any discussion of primitive accumulation - save perhaps for those historical studies concerned with how the transition to capitalist social relations takes place in different parts of the world. In this section, then, I want to address this debate on primitive accumulation and argue that it continues to be a useful concept for theorising the constitution and reconstitution of world order.

Whereas Adam Smith tried to account for an original accumulation of stock by imagining two races of people - one industrious and frugal, the other lazy and prone to immediate consumption - Marx rearticulated Smith's entire problematic by searching for historical accounts and evidence of this period of so-called 'original accumulation'. What Marx was most concerned to show was that capitalist economic development did not stem from a mythical period of original accumulation carried on peacefully or from an extensive division of labour. Instead, Marx focused on how a specific transformation in social property relations led to a new mode of exploitation and wealth generation for a capitalist propertied class. For Marx, the social property relations of capital were born of force and fraud and were first realised in England. Here, Marx recognised the importance of the politico-juridical apparatus in carrying out and securing the expropriation of direct producers. In this sense, primitive accumulation was essentially the process of waging a war of internal (and later external) colonisation whereby a privileged class of landlords and merchants came to constitute a new form of private property, primarily by expropriating direct and/or independent producers. Once this new form or property was de facto constituted, the owning class sought to secure their claims to ownership with a new juridical armature that subordinated royal sovereignty to property. ${ }^{16}$

By expropriating the peasantry through successive techniques, property owners created the conditions in which it was virtually impossible for increasing numbers of people to survive outside market relationships. What this means is that human survival, perhaps for the first time in history, was made contingent upon certain market imperatives. ${ }^{17}$ For Marx, this represented a new mode of exploitation, because without direct access to land and the means of livelihood, more and 
more people were compelled to sell their capacity to labour to someone else in return for a wage. In other words, non-property owners were made socially dependent on property owners for their life-activity. This represented a new social relation of power for Marx not simply because people had been stripped of their ability to work directly for themselves and their families, but also, and more importantly, because Marx supposed that workers added more value to the products they created during the labour process than what they were actually paid by their capitalist employers.

The question addressed in one of the current debates on primitive accumulation is whether this interpretation of primitive accumulation can help explain current events or whether it should simply denote an initial transition to capitalism. Those who argue within the historical primitive accumulation vein contend that once the revolution in social property relations is legally and politically guaranteed by capitalist owners and their supporters, the process is complete and the real forces or laws of accumulation can take over. What this entails is that the mechanisms of primitive accumulation have a historical point of cessation since the continuance of human exploitation for profit can be carried out under market disciplines that disguise not only the origins of capitalist profit, but also the relations of dominance and power that made this mode of exploitation possible in the first place. For instance, Paul Zarembka argues that since the separation of the worker from the means of production characterises both primitive accumulation and accumulation proper, the prefix 'primitive' is applied by Marx simply in order to describe the historical transition from feudalism to capitalism. ${ }^{18}$

Outside Marxist quarters, the debate becomes even more complicated when we consider one of the most recent and novel theories of capital and accumulation. Informed by Thorstein Veblen's political economy and originating from a critique of neoclassical as well as orthodox Marxist theories of capital and accumulation, Nitzan and Bichler argue that capital is primarily a 'strategic, power institution' whose capacity to generate earnings and beat an average rate of profit is capitalised by owners/investors. ${ }^{19}$ In this theorisation, the politics of production (rather than production per se) and the power of dominant corporations to shape the terrain of social production and reproduction in order to accumulate take centre stage. ${ }^{20}$ What this means is that power itself is a vendible commodity. This is so for at least two reasons.

First, the ability to generate earnings over time implies that the full productive capacity or efficiency of humanity must be strategically sabotaged as a going concern of any business enterprise. In this sense, the business enterprise is not committed to maximising production or even increasing productivity as an end in itself, but rather to controlling production and productivity for profitable ends. This sabotage is strategically necessary because too much productive capacity can threaten earnings. Thus the source of accumulation in Nitzan and Bichler's formulation is not productivity as such, nor is it the exploitation of workers who produce over and above what they are compensated in money. For them, profit is a direct result of a firm's control over the productive potential of humanity and its capacity to influence the course of human development and reproduction. However, since all firms must sabotage in order to accumulate, Nitzan and Bichler believe that there is an average rate of sabotage whose 
typical expression can be found in the normal rate of return for any given index or benchmark of accumulation - for example, the Nikkei 225 or the S\&P $500 .^{21}$ The goal of corporate executives or money managers is to beat the average rate of return. This brings us to the second reason why the politics of production and the power of business firms takes centre stage in this new theory of capital.

For Nitzan and Bichler, the earnings of dominant capital groups depend upon broader social, cultural and political processes and less on the ability of individual firms to control production within their own corporate organisations. In order to beat the average rate of profit, corporations must attempt to redistribute a larger share of earnings away from their competitors in the corporate universe. What this means is that corporate executives must do all they can to shape the social, cultural and political terrain in their favour. For example, the corporate earnings of Apple Computer Inc. do not simply depend upon the ability to produce its range of iPods or other goods and services by directing the labour of its workers. Rather, their corporate earnings, and the willingness of investors to bid up the price of existing shares, depend upon a whole range of factors that the corporation may wish to influence: the perception that portable $\mathrm{mp} 3$ players are a necessity; their ability to press for new markets and trade agreements with other legal jurisdictions; the ability of the state to punish violators who infringe their intellectual property rights; the quality of their lobbyists; their public reputation; accounting practices and standards; the ability of its consumers to access credit; the ability to influence anti-trust legislation and so on. What is of note is that the economic performance or earning capacity of firms is not based simply on the goods and services they offer for sale, but on a range of factors whose potential impact on a company's net income is taken into account or discounted by investors.

This understanding of accumulation leads Nitzan and Bichler to argue that 'power is both the means and the end of accumulation'. ${ }^{22}$ Put simply, this means that corporations exert whatever power they have over society and politics in order to generate earnings and beat the average rate of profit. If they are successful in their quest, the price of their ownership claims (stocks and corporate bonds) will increase, as well as their overall market capitalisation. The monetary magnitude of a firm's capitalisation indicates not only its 'power to restructure society and affect its overall development ${ }^{23}$ relative to other firms, but the perception of owners and investors that the firm will be able to do so in the future. For example, Exxon was the eighth largest capitalised business enterprise in April 1999 with a market value of US\$181 billion. In December 1999, the total value of its outstanding shares jumped to US\$282 billion thanks largely to its acquisition of Mobil. By January 2006, Exxon Mobil became the largest capitalised firm in the world with a market value of US $\$ 381$ billion, largely because of its record profits generated by instability in the Middle East and devastating hurricanes in the USA. In just over five years, then, Exxon Mobil's capitalisation more than doubled. ${ }^{24}$

If Nitzan and Bichler are correct, behind this movement is a whole history of corporate power deployed to 'restructure society and affect its overall development ${ }^{25}$ Indeed, even a cursory glance at Exxon's dealings since the late 1990s reveals some startling initiatives. Some of Exxon Mobil's actions during this period include: lobbying the European Commission, the US Federal Trade Commission and politicians on Capitol Hill in order to get its merger with Mobil 
approved in 1999; lobbying the US State Department to lift sanctions on Libya to exploit its oil wealth; volunteering to train Iraqi oil workers; influencing public perceptions by funding institutions who deny global warming and advising the George W. Bush administration to abandon the Kyoto global warming treaty; hiring and supplying local military personnel in Aceh in order to protect its natural gas fields; garnering public funding from the World Bank in order to help finance its operations in Chad and Cameroon; potentially conspiring with British Petroleum to restrict the supply of natural gas from Alaska; appealing the US\$4.5 billion dollar settlement awarded in a class-action suit to victims of the Exxon Valdez oil spill; influencing US Vice-President Cheney's Energy Task Force; and lobbying to drill in Alaska's Arctic National Wildlife Refuge. The list could go on. ${ }^{26}$ The point is that all of these factors - which involve the politics and power of production rather than production per se - enter into the potential profitability of Exxon Mobil and the decision of investors to capitalise the firm.

If we take this convincing new theory of capital as our starting point, then continuing to talk about primitive accumulation seems largely redundant. This is because Nitzan and Bichler's understanding of capital and accumulation begins from the point of view of capitalisation. In other words they ask: what is being capitalised and why? If investors/owners are indeed capitalising commodified forms of power when they purchase ownership claims to business entities, and corporations exert power over politics and society in order to generate earnings and beat a given average rate of return, then all of the strategic attempts of firms to 'accumulate by dispossession', enclose or commodify human life and resources are nothing more than moments in the process of accumulation. ${ }^{27}$ Put simply, in their view there is nothing 'primitive' about accumulation. ${ }^{28}$

However, one of the difficulties of Nitzan and Bichler's theory lies in accepting it without a history. It is a persuasive and compelling narrative based on convincing empirical evidence, but one that would be more forceful with a history beyond their transhistorical claim that the rulers of civilisations have always sought 'to control nature and people'. ${ }^{29}$ This is not to say that Nitzan and Bichler fail to recognise the historical specificity of capitalism as a new form of power and control with a universalising trajectory based on the commodification and accumulation of power. Indeed, at the very heart of their theory is the notion that capital is distinguished from all previous forms of ruling civilisations due to its relatively systematic quantification and commodification of power, but the problem lies in explaining its historical development. For example, as far back as the thirteenth century, Venetian bankers traded in government securities in line with Nitzan and Bichler's account of capital as a process whereby power is commodified and quantified. We may do well to find the origins of capital and its development in the Italian city-states. The problem here is that while there were incipient forms of capitalisation in public securities and thus one could contend from the point of view of their theory a commodification of power, there was no ability to extend the systematic quantification of power along a universalising trajectory. What was needed was not simply the commodification and quantification of powerful institutions capable of shaping a part of the social process, but the commodification of a particular kind of power whose purchaser 
does not have absolute ownership over the thing. That power is the capacity to labour for a set period of time in return for a wage and this required a particular kind of societal transformation that the so-called political Marxists or historical materialists have traced specifically to England. ${ }^{30}$

As these scholars have been at pains to emphasise, the possibility of capitalist development was historically realised in the English countryside where very specific pre-capitalist social property relations prevailed - relations that eventually encouraged and even permitted the systematic commodification of labour power by historically new economic imperatives. I will not rehearse the intricacies of the transition debate here, but the point of crucial importance is that it is in the English countryside where we find the first mass waves of landlords expropriating the rights of the peasantry through changes in land tenure. Through force, fraud, economic necessity and a developing market in land and competitive rents, more and more peasant producers were separated from their immediate access to the means of survival. However, this transition did not immediately translate into a class of wage-labourers easily exploitable by capital.

Indeed, according to Karl Polanyi, it was only in 1832 with the repeal of the poor laws that a truly 'free' market in labour became a reality. Without this commodification of labour and the commodification of money and land that preceded it, the accumulation of money on a potentially endless scale would have been impossible. Thus, even if we were to accept Nitzan and Bichler's account of capital and its accumulation in our own era, we must admit that it rests on an initial transformation in social property relations and that this process has not been sufficiently addressed by their theoretical framework. Because primitive accumulation has an international dimension insofar as more and more political communities have undergone this transition in social property relations through moments of combined and uneven development (China, Vietnam and the former Eastern European Bloc are perhaps the most recent examples), the concept of 'primitive accumulation' is of particular importance for those who want to account for the historical constitution of capitalist sociality. ${ }^{31}$

Yet this argument has only solved why the concept of 'primitive accumulation' may be of continuing importance for scholars of international relations who are concerned with accounting for the transition to a more universalised form of capitalist sociality. This brings us to the important question of whether the concept is still useful for explaining key components of contemporary international relations, political economy and the creation of a world order for corporate capital.

The problem with interpretations that want to relegate primitive accumulation to the past is that by doing so they tacitly agree to the notion that the social relations of capital pervade everywhere on the planet. In other words, these theorisations tend to assume the complete 'death of the peasantry' or other social formations, and therefore a full-blown capitalist sociality in which all human beings are subject to the same market imperatives for their survival - a claim that has been significantly undermined. ${ }^{32}$ The second difficulty with relegating primitive accumulation to the past is that it denies or at least underplays the possibility of resistance to capitalist initiatives and market imperatives. In other words, it not only ignores the presence of social forces which actively and consciously oppose their own subjugation to market imperatives, but also denies that these 
same forces can be successful in their attempts to mitigate, curtail or even liberate themselves from market compulsions and the power of capital. In this regard, it is worthwhile to consider the work of Massimo De Angelis, perhaps the first critical scholar to offer a dialectical theory of the ongoing nature of primitive accumulation in the face of resistance.

\section{(Primitive) accumulation and resistance}

Much like Nitzan and Bichler, De Angelis understands 'capital not as a totalised system, but as a force with totalizing drives'. ${ }^{33}$ What this means is that anything can potentially become a facet of capital through enclosure, expropriation and commodification, and indeed Nitzan and Bichler might tell us that all capitalist activity revolves around ownership and thus exclusion and enclosure. But the chief difference between their theorisation and the one offered by De Angelis involves the question of resistance. For De Angelis, it is not only important to consider the ways in which capitalist power is exerted over society, but also the ways in which the collective forces of society can erect social barriers to the accumulation of capital. These social barriers can perhaps be conceived along a continuum where one extreme represents life's total mediation by the market and the other extreme represents life's total independence from market exchanges. For example, any political community with a public health care system that is universally accessible by virtue of citizenship has erected a social barrier to life's full mediation by the market mechanism in access to health services. In this case, the public has excluded a field of potential accumulation from capitalist ownership. Of course, firms interested in profiting from the illnesses and injuries of human society may seek to dismantle and/or open up this field to business imperatives, but the fact remains that people have struggled and continue to struggle to erect social barriers to life's full mediation by the market in many fields. This is reminiscent of Polanyi's idea that the social dislocations caused by market imperatives generate various forms of struggle, albeit not always with progressive outcomes.

It would be unfair, however, to say that Nitzan and Bichler do not have a register for struggle in their theorisation of capital as power. While their main concern is not resistance to capitalist imperatives from below, they do account for resistance from the perspective of business firms in two main ways: active and passive. ${ }^{34}$ First, because the accumulation of differential power, as measured in monetary magnitudes, requires deliberate and active intervention on behalf of business firms, the process of accumulation necessarily entails struggles and counter-struggles between firms, as well as between firms and the rest of society. The second way Nitzan and Bichler register resistance is through their concept of passive differential accumulation. Investors can simply wait for the price of their securities to go up over time or corporate investors can discount moments of resistance into their asset prices. Resistance, therefore, can become a facet of capital accumulation when investors bid down the price of corporate shares due to struggles or potential struggles that look to threaten the expected profitability of the firm. To illustrate what appears to be a subtle difference between De Angelis' understanding of resistance and Nitzan and Bichler's, we can take the case of water privatisation in Cochabamba, Bolivia. 
From De Angelis' perspective, the public supply and availability of water at reasonable prices, not to mention the direct access Bolivians had to water wells, would already represent a social barrier to capital arrived at through historical struggle. Because these forms of access represent a barrier to accumulation, particularly for those companies whose profits stem from water-related activities, these firms may seek to breakdown these forms of access in their quest for greater net income. Given that the distribution and sanitation of water was eventually privatised in Bolivia, De Angelis might point to the agreement signed by the Bolivian government with the World Bank as a moment of primitive accumulation. This moment represents both the breakdown of a social barrier to private ownership and the process by which a public resource is commodified for profit. As such, it created a new form of market dependence for Bolivian citizens and the possibility for resistance from below. This is not simply because water is essential for life, but because the corporate control of water gives the firm the power to deny water access to those who cannot pay. As water costs increased dramatically under corporate control, coordinated resistance soon followed, leading to the re-socialisation of Cochabamba's water system. ${ }^{35}$ What this points to is the possibility of theorising resistance from below as a constitutive moment in the process of primitive accumulation.

From the perspective of capital as power, this struggle is indicative of active differential accumulation insofar as Bechtel (through its subsidiary Aguas del Tunari) deliberately sought control over Cochabamba's water system as part of its corporate strategy. It may also represent passive differential accumulation insofar as their theory would anticipate that smart corporate investors could have discounted this resistance movement into their asset prices.

Yet, while this may be an accurate account from the viewpoint of corporate owners, it does little to focus our attention on how and why people continue to struggle against the full instantiation of market imperatives. It also tends to overlook an entire history of resistance and the possibility for resistance in the future. But the concept of primitive accumulation seems to be important precisely because it focuses our attention on the very processes by which people are increasingly separated from non-market access to the means of life and the various ways they come to resist capitalist imperatives by setting up social barriers to the further commodification of life and nature. In this sense, the concept acts like a flashlight, illuminating moments of dispossession and resistance. It tells us not simply that power is being exerted over us, but that there is a struggle running through the entire history of capital and its attempt to control human and natural life through commodification and enclosure. One way to understand this struggle in our own conjuncture of the new occupations is to connect the concept of primitive accumulation with Nitzan and Bichler's concept of the capitalisation of the state.

\section{Capitalising sovereign power}

Scholars have so far failed to appreciate the ways in which the politico-military apparatus of the USA has been capitalised and how this is intimately connected with primitive accumulation and the international or global expansion of market imperatives and resistance. What seems to be peculiar about the political 
economy of the USA is its continued ability to attract a seemingly endless stream of capitalisation for its income-generating assets when previous hegemonic states witnessed a massive haemorrhaging of capital. This too may be subject to change and some have even predicted that US economic hegemony is in decline and will eventually shift to Asia. ${ }^{36}$ There are of course a number of possible explanations for this magnetic effect, ranging from the expected future profitability of firms listed on US stock exchanges to comparatively low levels of risk for corporate bonds and government securities. But while providing explanations for this ongoing capitalisation of America's political economy as a whole is certainly worthwhile, it might be more important to seek answers for the continued capitalisation of the sovereign power of the USA, registered by claims on the federal government and, by extension, the US public.

This is important for at least two reasons. First, the US Treasury market is the largest financial market in the world and, if we can consider, as Nitzan and Bichler do, the state as a capitalisable entity measured in the amount of debt owed to its creditors, the US federal government is the world's largest capitalised entity. ${ }^{37}$ This obviously begs the question of what investors are buying when they purchase US sovereign debt obligations. The answer is far from self-evident, but a first approximation might suggest that investors are purchasing claims on the government's ability to raise enough revenue to pay back its creditors with interest. The second reason for focusing on the sovereign power of the USA is that its massive spending on the means of force and coercion far exceeds that of other countries. Indeed, of all world military expenditures, the USA accounted for 47 per cent in 2004. According to the Stockholm International Peace Research Institute, US military spending in 2004 was "more than the combined total of the 32 next most powerful nations'. ${ }^{38}$ Whether we consider this 'defence' spending or not, what is eminently clear is that the security apparatus of the USA has extended far beyond its national borders by way of military bases and the capacity to deploy its forces anywhere in the world - a trend facilitated by the increasing privatisation of national security and the militarisation of space. ${ }^{39}$

The fact that the US federal government is the largest capitalised entity in the world and also happens to be the world's largest military spender should lead us to seek answers for the continued capitalisation of the sovereign power of the USA, especially when it has become increasingly popular to predict the USA's financial demise and its inability to shape the future constitution of world order. ${ }^{40}$ Part of the answer involves investigating the sovereignty-primitive accumulationsocial reproduction series. Tracing this series, my main argument runs as follows:

1. Sovereignty. The sovereign power of the USA, embedded in the strength of its politico-military apparatus and the ability of its political class to define the 'national interest', is capitalised by investors and registered or measured by the outstanding public debt to its creditors. The USA invests a large portion of this finance in its future ability to project power globally and intervene and wage war relative to other countries. In this sense, statements on how the USA will deploy its sovereign power, such as the National Security Strategy 2002 or US Space Command's Vision 2020, can be considered a 
kind of investment prospectus; they give creditors considerable indication of how the USA will mobilise its military power in the future.

2. Primitive accumulation. Intervention and war can be considered a mechanism of primitive accumulation insofar as the stated purpose of the US government is the reconstitution of political economies as open market economies capable of providing a more global field of operation for business firms and access to strategic assets. This entails breaking down 'social barriers' or mechanisms that grant some degree of non-market access to the means of life.

3. Social reproduction. The creation of market economies leads to a particular pattern of social reproduction whereby more of human life on the planet is mediated by the imperatives of the market and the capitalist firms that dominate them. However, in reproducing their social life, human beings often find ways to resist the full instantiation of market imperatives. Thus the attempt to radically transform the social property relations of a country, particularly by military force, is always a contested project.

If this is an accurate assessment of how the capitalisation of US sovereign power, primitive accumulation and the social reproduction of human life are connected, how might we be able to explain this historically as well as theoretically?

\section{Sovereign power and the creation of 'public' debt}

A first cut at the problem might consider and build on Marx's initial writings on the state and primitive accumulation. In his historical sketch on the origins of capitalist development, Marx recognised that the transformation to capitalist social property relations - both in England and in the colonies - would have been impossible without the power of the state or what he called the 'concentrated and organised force of society'. ${ }^{41}$ With the incorporation of the Bank of England in 1694 and the subsequent creation of the national and long-term debt, Marx argued that the English state had been effectively alienated by sale. ${ }^{42}$ What Marx meant by this was that the state was largely in the hands of the people who financed its operations - a fact made possible by the English Civil War and the violent suppression of alternative political projects.

Before the war, the Crown in England had to finance its operations by the income it derived from its royal estates and a limited system of taxation. When monarchs could not finance their initiatives from these two sources of revenue, they contracted private debt. In other words, when monarchs borrowed, it was not the public's debt, but their own personal obligation. ${ }^{43}$ Yet, since monarchs could not be tried in any of the nation's courts, they had the power to force private citizens to lend them money on favourable terms, and could even repudiate their debts. When this proved more difficult for successive monarchs due to heavy resistance from money lenders, shifts in the balance of power between the monarchy and its subjects, and ongoing and impending wars, the monarch would either sell off portions of the royal estates to private citizens or seek to increase or extend the level of taxation on the population. ${ }^{44}$ The English Civil War, the Glorious Revolution of 1688 and the subsequent creation of the Bank of England altered this financial arrangement. 


\section{The 'Art' of Colonisation}

In combination, these events had serious consequences for the future of England's political economy - and we might add, the world's. First, they changed the very nature of sovereign authority by democratising it for the propertied class. This could only be accomplished by eliminating the monarchy's exclusive power to raise its own funds and spend them at its discretion. The newly victorious parliamentarians ensured that this would be the case, first by abolishing the royal prerogative to tax, and second by granting the monarch a set amount of funds that would be closely audited. ${ }^{45}$ With sovereign power redefined, the moneyed and propertied classes could effectively lend to themselves and control fiscal policy to ensure timely payments of interest on the debt and the principal when debt obligations came due. However, this was not interpreted as the debt of a class lending to itself in order to further its own advancement and enrichment. Rather, the debt was interpreted as a 'national' or 'public' debt collectively owed by the people of the realm:

The public concept, when applied to the capital market, rests on the notion of national issue and guarantee of state debt. State finance became public finance when a governing body representing the people of a nation, not the king alone, borrowed funds for the state. In its capacity as public representative, the governing body contracted loans. The legislature was legally liable to provide adequate tax revenue to pay interest on the public debt, and to redeem principal when it came due. ${ }^{46}$

The concept of the national as opposed to the royal debt transformed the political economy of the English state once investors could be convinced that the government had sufficient power to ensure an adequate collection of revenues through taxation. Subsequent to this new financial innovation, the taxation, administrative and war-making apparatuses of the English state ballooned. ${ }^{47}$ While we do not need to dwell on the various mechanisms used to extract money from the people in order to repay rich creditors, the important point to note here is that, without the 'national' debt, private finance would not have been as forthcoming and the geographical scope and intensity of primitive accumulation, as well as capitalist development, would have been far more limited. Marx realised this connection when he noted how colonial wars and the capacity to wage them, the national debt, the system of taxation and the system of tariff protection arrived on the historical scene together. ${ }^{48}$ While Marx recognised the important role played by public credit and the taxation system as an expropriating agent, he did not develop a theory of the capitalisation of the state, nor did he conceive of power as a vendible commodity in his theory of accumulation.

Whereas Marx did not develop such a theory and the Marxist tradition has almost completely neglected the alienation of the state by sale and the wider implications of theorising its power as a commodity, Nitzan and Bichler have sought to offer a more comprehensive explanation. ${ }^{49}$ In fact, the idea that the state is capitalised and that its power and operations are essentially commodified can be attributed entirely to Nitzan and Bichler's original theorisation of capital as a form of power that shapes and reshapes the social process. As they note: 
The modern nation state, from its very beginning, was highly dependent on capitalist finance, whilst capitalisation was similarly reliant on state power. Indeed, it was this fusion between them which gave rise to the first form of modern capital - the government bond - whose very essence was the private ownership of the government's power to tax. Since then, the overlap grew deeper and wider, with an increasing proportion of capital values depending on, and in turn dictating the nature of key political institutions and organizations. ${ }^{50}$

While the capitalisation of the state was not the first form of capitalisation, it was undoubtedly the most important and far-reaching because of the state's monopoly over the means of force and its ability to use this force in order to collect taxes, open up new territories for exploitation and create the politico-juridical apparatus needed to protect and often extend the rights of private ownership. Moreover, as Nitzan and Bichler point out in the quote above, as small business concerns developed into capitalised entities themselves, their net earnings increasingly depended upon and influenced the shape of 'key political institutions and organizations'. For example, mortgaging the public revenues to private creditors not only changed the nature of the Exchequer and the information it collected during the financial revolution in England, but it also led to the very creation of joint-stock companies, a more extensive system of taxation and the development of a professionalised and increasingly well-equipped military. ${ }^{51}$

For Nitzan and Bichler, however, the commodification of the state does not simply mean that its powers to tax have been effectively privatised. They also point to the fact that investors increasingly discount state policies since they invariably impact upon corporate profits. What this means is that investors are increasingly anticipating the actions of government actors and assess their impacts on future profitability and adjust their expectations accordingly - a process made more predictable by panoptic strategies and lobbying efforts. ${ }^{52}$ For example, suppose that energy and automotive firms lobbied the US government in an attempt to encourage it not to ratify the Kyoto Protocol. Investors could anticipate the success or failure of this endeavour based on comments and affirmations made by politicians and therefore take this into consideration when deciding whether to invest, discount or ultimately divest from an automotive or energy corporation. When this occurs, and Nitzan and Bichler believe that it increasingly does, then government decision making itself becomes a facet of capital.

Yet there is more to the story. Nitzan and Bichler conceive of the modern corporation itself as an incipient form of state, insofar as firms come to control ever more facets of life and planetary resources. To some this might seem like a wild stretch of the imagination, but a brief example may serve to highlight the parallels between the modern corporation and the state. If it is true that government bonds ultimately represent the privatisation of the government's power to tax, then it is not impossible to conceive of the corporation as an embryonic form of state. For example, the modern food system is largely controlled by giant food service corporations and global agribusiness. ${ }^{53}$ Because many people on the planet do not 
produce their own food for consumption, we rely primarily on these corporations in order to eat and live. When investors capitalise these firms, they are essentially investing in the privatisation of food production and the power of these firms to attract customers to their individual products or services. The parallel with governmental apparatuses and the food corporation is that they are both commodified forms of power, albeit in different fields: one capitalises the power to tax (among other powers), the other the power to make profit by supplying, or sometimes not supplying, food. ${ }^{54}$ As more and more people depend on market exchanges to mediate their existence, and as the market becomes increasingly dominated by giant corporations - some with revenues larger than the gross domestic product of most countries - it is not inconceivable to think of corporations as an incipient form of state given their 'social centrality' to everyday life. ${ }^{55}$

While I agree with Nitzan and Bichler that the commodification of the state ultimately represents the privatisation of the government's power to tax, what their theorisation largely ignores is how the financing of the US government and, by implication, its politico-military apparatus is intimately connected with global moments of primitive accumulation that set the stage for a more market-oriented process of social reproduction. Indeed, in their accounts of the new wars Nitzan and Bichler do not seem excessively concerned with transformations on the ground and the resistance this process has generated. However, before examining the intimate connection between the capitalisation of sovereign power, primitive accumulation and social reproduction in relation to the new art of colonisation in Iraq, I want to demonstrate how the capitalisation of the US military and its role in shaping the terrain of social reproduction along more market lines is understood in the minds of many 'security policymakers, Wall Street heavyweights, and academic experts'. 56

\section{Capitalising 'futures worth creating'}

It's for real. The for-profit nation-state, with a globally dispersed citizenry of shareholders, is the next stage in the evolution of political economy. ${ }^{57}$

Critical as well as orthodox scholars have noticed the work of Thomas P. Barnett as an important testament of US Grand Strategy and its stated commitment to economic globalisation. ${ }^{58}$ However, few have understood his work from the vantage point of capitalisation. Following up on his article in Esquire, Barnett published a book in 2004 entitled The Pentagon's New Map: War and Peace in the Twenty-First Century. In the text, Barnett is concerned to demonstrate how he is the cartographer of the Pentagon's new map for military intervention into the foreseeable future. He conceives of the USA as a global Leviathan whose sovereign bonds are capitalised by foreign and domestic investors because the USA offers investors a 'future worth creating' by providing 'the world a security product that is unrivaled'. 59 In other words, Barnett conceptualises the politicomilitary apparatus of the USA and its capacity to shape the future contours of world order as a commodity purchased by investors. From this it follows that 
investors will continue to finance US debt as long as its politico-military apparatus appears capable of exerting a controlling influence on the future constitution of world order. This might sound like an unconventional and even crude understanding of the state, but it was not developed by Barnett alone.

Barnett's new map was facilitated by war game simulations sponsored by the global financial service provider Cantor Fitzgerald and the Naval War College. According to the Pentagon's new cartographer, seeing the world through a bond firm's eyes allowed him to pinpoint the locations where the USA would likely intervene in the future to create market economies. In drawing this new map, Barnett divides the world into three categories and states fall into these categories according to their degree of economic openness and their general commitment to providing a safe and secure environment for business firms. Governments that have accepted and seek to liberalise markets constitute the Core; governments that show some commitment to open markets and the security of property constitute the Seam; and governments that have failed to connect their economies to the global market are labelled the Gap. The strategic goal is to use the politico-military apparatus of the USA to shrink the Gap states by transforming them into open market economies with the capacity to secure the rights of capitalist ownership and perhaps other liberal freedoms. Once the international states system is mostly constituted by stable and open market economies, Barnett argues that the prospects for global peace will improve significantly. This is the Pentagon's 'future worth creating', and Barnett contends that it is sold to investors when they purchase US government securities. It is a future world order where warfare becomes increasingly rare because the 'silent compulsions of the market' are presumed to dictate life chances and outcomes.

As Barnett suggests, the continued ability of the US politico-military apparatus to act abroad is indeed contingent upon its ability to finance its operations by issuing debt. As an indication of just how crucial this is, the George W. Bush administration has recently had to plead with Congress to 'increase the statutory debt limit to nearly $\$ 9$ trillion ... to avoid a default and keep the government operating' ${ }^{60} \mathrm{~A}$ further indication of the USA's need for finance is the recent return of the long bond, a 30-year debt instrument that was eliminated by the Clinton administration based on the projection of real and estimated fiscal surpluses. With the Bush administration's foreign and domestic policy agenda in dire need of finance, the long bond's return may well be taken as a sign of necessity and, perhaps, imperial desperation. ${ }^{61}$

But when Barnett maps out the potential future targets of US military intervention he is doing something more without realising it. He is also mapping out the countries where the social property relations of capital are not deeply embedded and where the politico-juridical order of a state has made it difficult or impossible for transnational firms to seek out new fields of investment and profit potential. The following section on Iraq provides considerable evidence to suggest the connections between the ongoing capitalisation of the sovereign power of the USA and attempts to re-engineer temporarily occupied societies along market lines. ${ }^{62}$ 


\title{
Transformation and resistance in occupied Iraq
}

This is not liberation, it is occupation. At the beginning of the twenty-first century, we thought we'd seen the end of colonies, but now we're entering a new era of colonisation.

\author{
Ghasib Hassan ${ }^{63}$ \\ (A leader of the Iraqi Federation of Trade Unions)
}

There is hardly any debate that the engineers of Iraq's occupation intended to transform Iraq's political economy from one premised upon socialism to one more fully amenable to market imperatives. Under the Provisional Constitution of 1970, in force until the occupation, the full realisation of market imperatives and disciplines was blocked since Iraqi citizens had rights that granted them a considerable degree of non-market access to the means of survival. ${ }^{64}$ In other words, the Provisional Constitution acted as a kind of social barrier to the full mediation of life by capitalist markets, while at the same time precluding Iraq from full membership into the liberal capitalist international order being constructed by the USA in the post-war period. For instance, the Constitution guaranteed the right to free education up to and including the university level, the right to employment and free medical care for all citizens. The Constitution also interpreted Iraq's national resources and the nation's means of production as the people's inviolable property and could only be employed by the state for the benefit of the national economy. Furthermore, while the constitution did not disallow private property and even barred the state from confiscating it without due compensation, it defined the ownership of private property as a social privilege that could be rescinded if its use was considered detrimental to the interests of the Iraqi people. The constitution also sought to limit the size of agricultural land holdings so that titles to surplus land would be transferred to the state for potential redistribution and settlement. Although exceptions could be made for some individuals, foreigners were prohibited from owning real estate by the provisional constitution.

While not all of these freedoms and rights were guaranteed in practice, after 1970 Iraq became the most economically and socially developed state in the Arab world. Among the achievements were rising standards of living for urban populations, one of the best health care and educational systems in the Middle East, an increased literacy rate, increased agricultural productivity, public service provisioning to the more destitute south and growing per capita income. A protracted and devastating war with Iran, the build-up of foreign debt as a result, as well as the invasion of Kuwait and the subsequent United Nations sanctions regime, altered the course of Iraq's quasi-independent nationalist development along more socialist lines. However, while there were some initial attempts in the late 1980s to liberalise Iraq's political economy and curtail labour resistance (for instance, the government banned unions), the more complete transformation of its social property regime followed on the heels of the occupation and many of the Orders established by the US-run Coalition Provisional Authority. For instance, Order 12 liberalises Iraq's trade policy; Order 56 gives the Central Bank of Iraq full independence from the Ministry of finance, thus depoliticising money and credit; Order 39 grants foreign investors the right to 
equal treatment under the law, rights to purchase business entities (with some restrictions), and full rights to repatriate profits. Other potential reforms include the privatisation of Iraq's public sector enterprises and the development of contractual arrangements that allow private corporations greater dealings in Iraq's oil industry. ${ }^{65}$ The financial cost to enact this transformation in social property relations has been estimated at somewhere around US $\$ 1-2$ trillion - a cost that must eventually be paid by the "middling ranks' of US tax payers. ${ }^{66}$ It is also a financial cost that is likely to mount as resistance to the occupation continues.

In Iraq, then, the connections between the deployment of state power, its capitalisation and the ongoing nature of primitive accumulation all come together in a display of attempted constitutional transformation and violent resistance. This resistance should be understood within a broader historical context of Islamist and nationalist resistance to the foreign domination of their political economies. ${ }^{67}$ Indeed, while the insurgency in Iraq consists of a number of groups and organisations (primarily of Sunni origin), and while their tactics, strategies and aims may ultimately differ, what appears beyond dispute is that the primary point of reference for their struggles is the US-led military occupation of the country, combined with an understanding that the right to decide the future of their own political economy has largely been expropriated by US technocrats and pro-occupation forces in and outside Iraq's parliament. As one conference of Iraqi unions declared: 'We are united in our opposition to the imposition of privatisation of the Iraqi economy by the occupation, the IMF, the World Bank foreign powers, and any force that takes away the right of the Iraqi people to determine their own economic fate. ${ }^{68}$ However, the resistance in Iraq is not simply spawned by the potential privatisation of Iraq's public sector. A number of other factors such as the indiscriminate killing of civilians by occupation forces, the construction of permanent military bases and a palatial US embassy, the torture and abuse of Iraqi prisoners, and high unemployment, food insecurity and poverty also contribute to the ongoing resistance. For instance, transformations in the social property relations of the country have already compounded the experience of insecurity for a number of Iraqis:

Price controls have all but disintegrated; petrol station owners demand a 'karamiya' (consideration) on top of the official price of 20 dinar per litre. Prices of flour, rice and cement have all tripled or quadrupled, according to interviews with Iraqis. Rents have shot up, putting families out on the street. Many of Baghdad's squatters say they have been evicted by landlords from flats whose rents were controlled under the former regime. ${ }^{69}$

Although this is only a cursory overview of some of the contested social property initiatives now being implemented in Iraq, the point has been to demonstrate the ongoing nature of primitive accumulation and its connection with the capitalisation of the US state. The strategic occupation and reconstitution of Iraq's political economy is at the same time an act of expropriation, insofar as it seeks to transform the social property relations of the country and do away with Iraq's previous socialist constitution and alternative understandings of 
development. This project, as well as others in Haiti and Afghanistan, would be impossible without foreign and domestic finance and the belief among creditors that the US government will be able to extract the necessary taxes from its citizens to repay the debt with interest. ${ }^{70}$ However, as the resistance to the US occupation of Iraq demonstrates, finance and military capability may not be enough to effect the changes desired by militant liberals.

\section{Conclusion}

Joseph Schumpeter once observed that "public finances are one of the best starting points for an investigation of society. The spirit of a people, its cultural level, its social structure, the deeds its policy may prepare - and this and more is written in its fiscal history. ${ }^{71}$ While this paper has only considered some of the recent fiscal history of the US government in relation to its intervention in Iraq, it demonstrates some of 'the deeds its policy may prepare'. One such endeavour has been the attempt forcibly to alter the social property relations of its occupied territories. Here, I suggested that Marx's re-theorisation of the concept of primitive accumulation, combined with a non-Marxist theorisation of state power offered by Nitzan and Bichler, can help us understand the connection between this developing strategic project and the ongoing capitalisation of the US government.

Although I am inclined to side with Nitzan and Bichler's theorisation of capital as commodified power, the concept of primitive accumulation remains important to explain the spatial expansion and deepening of market imperatives once we come to realise that the full instantiation of market imperatives, as Polanyi once recognised, is incongruous with human survival and thus generates spontaneous forms of progressive and often reactionary forms of resistance. Such resistance has produced and can produce social barriers that limit the power of capitalist firms to shape and reshape the terrain of social reproduction.

Part of explaining this dynamic of power and resistance, rests in a more extensive historical and theoretical understanding of state power and its application as a commodified entity that largely acts in accordance with the interests of its creditors and dominant capital groups, be they domestic or foreign. Since planners in the US government have consciously developed the capacity to intervene, occupy and reconstruct or reconstitute political economies with the express purpose of introducing the silent compulsions of the market, we would do well to consider it as one of the most important agents of primitive accumulation and social transformation. This holds insofar as the politico-military apparatus of the USA is mobilised to introduce, instantiate and intensify market imperatives in countries sheltered - even partially - from the full mediation of life by the market and the firms that dominate it.

There are of course a number of things at stake in this analysis of US sovereign power and its violent role in primitive accumulation. Chief among them, yet often overlooked, is the vital role citizens play when paying their taxes to the US government. Though the tradition of refusing to pay taxes for war in the USA dates to the American Revolution, its practice was perhaps best understood by Henry David Thoreau in his famous essay on civil disobedience: 'If a thousand men were not to pay their tax-bills this year, that would not be a violent and bloody 
measure, as it would be to pay them, and enable the State to commit violence and shed innocent blood. This is, in fact, the definition of a peaceable revolution, if any such is possible. ${ }^{72}$ There is little doubt that the struggle against war and foreign domination has had many sites and slogans. But perhaps the most important site is now currently in the USA where the National War Tax Resistance Coordinating Committee is waging a battle to redirect taxes away from war under the slogan 'if you work for peace, stop paying for war'. ${ }^{73}$ If the 10,000 war tax resisters continue to grow, then the fiscal history of the USA may indeed tell a very different story about the 'spirit of a people, its cultural level, its social structure, [and] the deeds its policy may prepare'.

\section{Notes}

I would like to thank Adrienne Roberts, Robbie Shilliam, Stephen Gill and Jonathan Nitzan for the many conversations that have helped shape this paper. The comments and suggestions of three anonymous reviewers also considerably strengthened the piece. All errors are of course my own.

1. Karl Marx, Capital: A Critique of Political Economy, Vol. 1 (Penguin Group, 1976), pp. 931-40.

2. Michael Perelman, The Invention of Capitalism: Classical Political Economy and the Secret History of Primitive Accumulation (Duke University Press, 2000), pp. 324-31.

3. Adam Smith, An Inquiry into the Nature and Causes of the Wealth of Nations (Oxford University Press, [1776] 1998), p. 208.

4. Matthew Sparke, 'American Empire and Globalisation: Postcolonial Speculations on Neocolonial Enframing', Singapore Journal of Tropical Geography, Vol. 24, No. 3 (2003), pp. 376-81.

5. Mark T. Berger, 'From Nation-Building to State-Building: The Geopolitics of Development, the Nation State System and the Changing Global Order', Third World Quarterly, Vol. 27, No. 1 (2006), pp. 5-25. See also, Adam David Morton, 'The Failed State of International Relations', New Political Economy, Vol. 10, No. 3 (2005), pp. 371-9.

6. National Security Strategy of the US, 2002, http://www.whitehouse.gov/nsc/nss.pdf (accessed 4 October 2006), p. 1.

7. Mark Duffield, Global Governance and the New Wars (Zed Books, 2001), pp. 29-39.

8. For an analysis of British taxation from the Restoration to the early nineteenth century, see Patrick K. O'Brien, 'The Political Economy of British Taxation, 1660-1815', The Economic History Review, Vol. 41, No. 1 (1988), pp. 1-32. On taxation and debt as a mechanism of primitive accumulation in the periphery, see Matthew Forstater, 'Taxation and Primitive Accumulation: The Case of Colonial Africa', Research in Political Economy, Vol. 22, No. 1 (2005), pp. 51-64. Also Karl Polanyi, The Great Transformation: The Political and Economic Origins of Our Times (Beacon Press, 1975), p. 164.

9. On their power theory of value see sections IV, V and VI in Jonathan Nitzan \& Shimshon Bichler, 'New Imperialism or New Capitalism?', Review, Vol. 29, No. 1 (2006), pp. 1-86.

10. Jonathan Nitzan, 'Differential Accumulation: Towards a New Political Economy of Capital', Review of International Political Economy, Vol. 5, No. 2 (1998), pp. 169-216, and Jonathan Nitzan, 'Regimes of Differential Accumulation: Mergers, Stagflation and the Logic of Globalization', Review of International Political Economy, Vol. 8, No. 2 (2001), pp. 226-74.

11. Stephen Gill, 'Globalisation, Market Civilisation, and Disciplinary Neoliberalism', Millennium: Journal of International Studies, Vol. 23, No. 3 (1995), pp. 399-423.

12. Massimo De Angelis, 'Marx and Primitive Accumulation: The Continuous Character of Capital's Enclosures', The Commoner, No. 2 (2001), pp. 1-22, and Massimo De Angelis, 'Separating the Doing and the Deed: Capitalism and the Continuous Character of Enclosures', Historical Materialism, Vol. 12, No. 2 (2004), pp. 57-87.

13. Julian Reid, 'The Biopolitics of the War on Terror: A Critique of the "Return of Imperialism" Thesis in International Relations', Third World Quarterly, Vol. 26, No. 2 (2005), pp. 237-52.

14. By sovereign power, I mean the capacity of the federal government and its agencies to shape and reshape the terrain of social reproduction both at home and abroad through various policies and techniques of government. However, in my view, the most important aspect of US sovereign power is force, particularly, though not exclusively, military force. 


\section{The 'Art' of Colonisation}

15. Robbie Shilliam, 'Hegemony and the Unfashionable Problematic of "Primitive Accumulation"، Millennium: Journal of International Studies, Vol. 32, No. 1 (2004), pp. 59-88; William Sites, 'Primitive Globalisation? State and Locale in Neoliberal Global Engagement', Sociological Theory, Vol. 18, No. 1 (2000), pp. 121-44; David Harvey, The New Imperialism (Oxford University Press, 2005); David Moore, 'Neoliberal Globalisation and the Triple Crisis of "Modernisation" in Africa: Zimbabwe, the Democratic Republic of the Congo and South Africa', Third World Quarterly, Vol. 22, No. 6 (2001), pp. 909-29; De Angelis, 'Marx and Primitive Accumulation'; De Angelis, 'Separating the Doing and the Deed', Massimo De Angelis, The Beginning of History: Value Struggles and Global Capital (Pluto Press, 2007); Paul Zarembka, 'Primitive Accumulation in Marxism, Historical or Trans-Historical Separation from Means of Production', The Commoner, March (2002), pp. 1-9; Silvia Federici, Caliban and the Witch: Women, The Body and Primitive Accumulation (Autonomedia, 2004).

16. John R. Commons, Legal Foundations of Capitalism (University of Wisconsin Press, 1959), and Polanyi, The Great Transformation, p. 38.

17. Ellen Meiksins Wood, Empire of Capital (Verso, 2005), pp. 6-7.

18. Zarembka, 'Primitive Accumulation in Marxism', p. 6.

19. Jonathan Nitzan \& Shimson Bichler, The Global Political Economy of Israel (Pluto Press, 2002), p. 31. My discussion of Nitzan and Bichler's framework primarily derives from this text.

20. We should note here that by production the theorists mean 'the entire spectrum of human activity', not simply factory work.

21. Nitzan \& Bichler, The Global Political Economy of Israel, p. 38.

22. Ibid., p. 10.

23. Ibid., p. 9.

24. Data on market capitalisation derived from charts found at: http://fortboise.org/top100-history.html (accessed 15 March 2006).

25. Nitzan \& Bichler, The Global Political Economy of Israel, p. 9.

26. On Exxon Mobil lobbying, see http://www.opensecrets.org/pubs/lobby00/topind04.asp and http:// www.corporatewatch.org.uk/?lid=294 (accessed 4 October 2006). On Exxon Mobil's lobbying to lift sanctions in Libya, see 'US business urging Bush to drop Libya sanctions soon', Reuters, 23 January 2004. On training Iraqi oil workers, see Justin Blum, 'Big oil companies train Iraqi workers free global companies offer services to establish goodwill, win business', Washington Post, 6 November 2004. On Exxon Mobil's funding of institutions that challenge global warming, see Jennifer Lee, 'Exxon Backs Groups that Question Global Warming', New York Times, 28 May 2003. On Exxon Mobil in Aech, see http://www.laborrights. org/projects/corporate/exxon/index.html (accessed 4 October 2006). On Exxon Mobil and the World Bank, see Miren Gutierrez, 'World: Murky Business in Oil', Inter Press Service, 20 August 2003. On Exxon Mobil's exploits in Alaska, see 'Alaska group files antitrust suit against Exxon Mobil, BP', Dallas Business Journal, 20 December 2005. On the Exxon Valdez spill settlement, see Evelyn Nieves, 'Court overturns jury award in '89 Exxon Valdez spill', New York Times, 8 November 2001. On Exxon Mobil and Cheney's energy taskforce, see Dana Milbank \& Justin Blum, 'Document says oil chiefs met with Cheney task force', Washington Post, 16 November 2005. On Exxon Mobil and Alaska's Arctic National Wildlife Refuge, see Justin Blum, 'Exxon Mobil Profit Soars 75\%', Washington Post, 28 October 2005.

27. Harvey, The New Imperialism, pp. 145-52.

28. Nitzan \& Bichler, 'New Imperialism or New Capitalism?, p. 37. Indeed, there appears to be a glaring methodological difference between Nitzan and Bichler's framework and traditional Marxists. However, in their work they seem to suggest that using the term 'primitive accumulation' necessarily implicates one in Marx's theory of accumulation as surplus labour. My own view is that this need not be the case, since the term 'primitive accumulation', as I understand it, only implies transformations in social property relations whereby the market comes to determine more and more of social life and its chances.

29. Nitzan \& Bichler, The Global Political Economy of Israel, p. 35.

30. Robert Brenner, 'The Origins of Capitalist Development: A Critique of Neo-Smithian Marxism', New Left Review, Vol. 104 (1977), pp 25-92; George Comninel, Rethinking the French Revolution (Verso, 1987); Ellen Meiksins Wood, The Origin of Capitalism (Verso, 1999); David McNally, Political Economy and the Rise of Capitalism: A Reinterpretation (University of California Press, 1988).

31. Shilliam, 'Hegemony and the Unfashionable Problematic', pp. 59-88.

32. De Angelis, 'Separating the Doing and the Deed', pp. 57-87, and Henry Bernstein, 'The Peasantry in Global Capitalism: Who, Where and Why?', in Leo Panitch \& Colin Leys (eds), Working Classes, Global Realities (Merlin Press, 2000), pp. 25-51. 


\section{Tim Di Muzio}

33. De Angelis, 'Separating the Doing and the Deed', p. 60.

34. For a discussion of active and passive dimensions of differential accumulation, see Shimshon Bichler \& Jonathan Nitzan, 'Dominant Capital and the New Wars', Journal of World-Systems Research, Vol. 10, No. 2 (2004), pp. 266-8.

35. Oscar Olivera \& Tom Lewis, Cochabamba: Water War in Bolivia (South End Press, 2004), and Susan Spronk, 'Roots of Resistance to Urban Water Privatization in Bolivia: The "New Working Class", the Crisis of Neoliberalism, and Public Services', paper presented for the workshop 'The Dynamics of NonTraditional Protest Politics', annual meeting of the Canadian Political Science Association, York University, Toronto, 3 June 2006.

36. Giovanni Arrighi, The Long Twentieth Century: Money, Power and the Origins of Our Times (Verso, 1994).

37. Doug Henwood, Wall Street: How it Works and For Whom (Verso, 1997), pp. 22-7.

38. Peter Starck, 'World Military Spending Topped \$1 Trillion in 2004', Reuters, 7 June 2005.

39. P. W. Singer, Corporate Warriors: The Rise of the Privatised Military Industry (Cornell University Press, 2003); US Space Command, Vision for 2020, 1997, http://www.fas.org/spp/military/docops/usspac/ index.html (accessed 3 October 2006); Chalmers Johnson, The Sorrows of Empire: Militarism, Secrecy, and the End of the Republic (Metropolitan Books, 2004).

40. Immanuel Wallerstein, 'The Curve of American Power', New Left Review, No. 40 (2006), pp. 77-94; Giovanni Arrighi, 'Hegemony Unravelling - I', New Left Review, No. 32 (2005), pp. 23-80.

41. Marx, Capital, p. 916.

42. Marx, Capital, pp. 915, 919.

43. Carolyn Webber \& Aaron Wildavsky, A History of Taxation and Expenditure in the Western World (Simon and Shuster, 1986), p. 252.

44. Richard Pipes, Property and Freedom (Alfred A. Knopf, 1999).

45. Michael J. Braddick, The Nerves of State: Taxation and the Financing of the English State, 1558-1714 (Manchester University Press, 1996), p. 44.

46. Webber \& Wildavsky, A History of Taxation and Expenditure in the Western World, p. 256.

47. Braddick, The Nerves of State, pp. 21-48.

48. Marx, Capital, pp. 915-6.

49. See Bichler \& Nitzan, 'Dominant Capital and the New Wars', pp. 33-41. My main point of divergence with the authors here is my consideration of England as the birthplace of capitalist social property relations. In their writings on the state and debt they tend to speak generally and schematically rather than offer a historically specific account of the rise of capitalism.

50. Nitzan \& Bichler, The Global Political Economy of Israel, pp. 13-14.

51. Braddick, The Nerves of State, pp. 27-34; Peter G. M. Dickson, The Financial Revolution in England: A Study in the Development of Public Credit 1688-1756 (St. Martin's Press, 1967), pp. 65-75.

52. Timothy J. Sinclair, The New Masters of Capital: American Bond Rating Agencies and the Politics of Creditworthiness (Cornell University Press, 2005); Stephen Gill, 'The Global Panopticon? The Neo-liberal State, Economic life and Democratic Surveillance', Alternatives: Global, Local, Political, Vol. 20, No. 1 (1995), pp. $1-49$.

53. Phillip McMichael, 'Food Security and Social Reproduction: Issues and Contradictions', in Isabella Bakker \& Stephen Gill (eds), Power, Production and Social Reproduction (Palgrave Macmillan), pp. 169-88.

54. Here it should be noted that food service corporations have an interest in profit generation, not food production. There is plenty of evidence to suggest that corporations will keep food out of the market in order to ensure sufficient pricing for their profitability. One example is the fact that in most industrialised countries farmers are paid not to produce. See Susan George, How the Other Half Dies: The Real Reasons for World Hunger (Allanheld Osmun, 1997).

55. Nitzan \& Bichler, The Global Political Economy of Israel, pp. 14-15.

56. Barnett, The Pentagon's New Map, p. 5.

57. Jonathan Franzen, The Corrections (Harper Perennial, 2002), p. 506.

58. Simon Dalby, 'Political Space: Autonomy, Liberalism, and Empire', Alternatives: Global, Local, Political, Vol. 30, No. 4 (2005), pp. 415-42; Stephen Gill, 'The Contradictions of US Supremacy', in Leo Panitch \& Colin Leys (eds), The Empire Reloaded, Socialist Register 2005 (The Merlin Press, 2004), pp. 23-46; Andrew Harvey, Ian Sullivan \& Ralph Groves, 'A Clash of Systems: An Analytical Framework to Demystify the Radical Islamist Threat', Parameters, Vol. 35, No. 3 (2005), pp. 72-87; James R. Holmes \& Toshi Yoshihara, 'China and the Commons: Angell or Mahan?', World Affairs, Vol. 168, No. 4 (2005), pp. 172-92; Barry C. Lynn, 'War, Trade and Utopia', The National Interest, No. 82 (2005), pp. 31-39; 


\section{The 'Art' of Colonisation}

Leo Panitch \& Sam Gindin, 'Global Capitalism and American Empire', in Leo Panitch \& Colin Leys (eds), The New Imperial Challenge, Socialist Register 2004 (The Merlin Press, 2003), pp. 1-38; Michael Wesley, 'Toward a Realist Ethics of Intervention', Ethics and International Affairs, Vol. 19, No. 2 (2005), pp. 55-73.

59. Barnett, The Pentagon's New Map, pp. 308, 310.

60. Carl Hulse, 'Senate approves budget, breaking spending limits', New York Times, 17 March 2006.

61. 'Long Ranger: Return of 30 year Treasury Bonds', The Economist, 4 February 2006, p. 67. Some analysts believe that increasing the rate of maturity by introducing the bond makes good financial sense since the costs of long-term borrowing are currently low.

62. While I deal exclusively with Iraq here, accounts of similar processes can be found in Haiti and Afghanistan. On Haiti, see Steve Lendman, 'Closing Haiti’s open veins: Rene Preval's impossible mission', ZNET, 2006, http://www.zmag.org/content/showarticle.cfm?SectionID=55\&ItemID=9847 (accessed 3 July 2005). For an overview of recent neoliberal reforms to Afghanistan, see World Bank, The Investment Climate in Afghanistan: Exploiting Opportunities in an Uncertain Environment, 2005, http://siteresources.worldbank. org/INTAFGHANISTAN/Resources/AF_ICA_Report.pdf (accessed 4 October 2006).

63. David Bacon, 'Iraqi unions defy privatization', The Progressive, October 2005, http://www.progressive. org/?q = mag_bacon1005 (accessed 5 April 2007).

64. The ensuing discussion on Iraq's provisional constitution draws on the country study of Iraq commissioned by US Department of the Army and published by the Federal Research Division of the Library of Congress. The country studies, which previously appeared in book form, are now accessible online. Iraq's overview can be accessed at http://countrystudies.us/iraq/ (accessed 25 January 2005).

65. On the oil contracts likely to be implemented in Iraq see, Greg Muttitt, Crude Designs: The Rip-off of Iraq's Oil Wealth, PLATFORM, November 2005, http://www.carbonweb.org/documents/crude_designs_large. pdf (accessed 5 April 2007).

66. Jamie Wilson, 'Iraq War could cost US over $\$ 2$ trillion, says Nobel Prise-winning economist', The Guardian, 7 January 2006.

67. Glenn E. Robinson, 'The Battle for Iraq: Islamic Insurgencies in Comparative Perspective', Third World Quarterly, Vol. 28, No. 2 (2007), pp. 261-73.

68. Bacon, 'Iraqi Unions Defy Privatization'.

69. Charles Clover \& Roula Khalaf, 'Dislocation, Loss and Tragedy', Financial Times, 22 October 2003.

70. Floyd Norris, 'Foreigners May Not Have Liked the War, But They Financed It', New York Times, 12 September 2003.

71. Cited in O'Brien, 'The Political Economy of British Taxation', p. 1.

72. Henry David Thoreau, Civil Disobedience, 1849, http://thoreau.eserver.org/civil.html (accessed 15 April 2007).

73. http://www.nwtrcc.org/mtap07/mtap0407.pdf (accessed 15 April 2007). 